\title{
COMMENTS
}

\section{WHEN DOCTRINES COLLIDE: \\ DISPARATE TREATMENT, DISPARATE IMPACT, AND WATSON V. FORT WORTH BANK E TRUST}

\author{
AnIta M. Alessandra $\dagger$
}

\section{INTRODUCTION}

An employer is responsible for making numerous decisions involving the initial hiring of its workforce, as well as subsequent determinations concerning salary, promotion, and transfer, which have a significant impact on individuals who work for the firm or apply for employment. It is therefore important that these decisions are made in a manner which is reasonable and free from any discriminatory effect. Often such determinations are made objectively through the use of standardized procedures, such as aptitude tests, that are neutral in their content and mechanical in their application. There is a second mode of decision-making by employers which instead uses a more subjective, individualized approach. For instance, rather than administering the same test to each candidate for promotion and selecting the employee having the highest numerical score, an employer following this second approach might choose to interview the candidates, with or without the aid of a defined set of desireable criteria, and form her own opinion of each candidate's performance and potential. In both selection methods there lies the possibility of discrimination.

Title VII of the Civil Rights Act of $1964^{1}$ ("Title VII") proscribes discrimination in employment on the basis of race, color, religion, sex, or national origin. The nature of Title VII protection varies, however, with the nature of the alleged discrimination. Two approaches have been used by plaintiffs to prove discrimination in employment decisions. Plaintiffs can allege disparate treatment: the employer intended

† B.A., B.B.A. 1987, Southern Methodist University; J.D. Candidate 1990, University of Pennsylvania.

1 Pub. L. No. 88-352, 78 Stat. 253 (1964) (codified at 42 U.S.G. $\$ 2000$ e to e-17 (1982)). The key provisions of Title VII became effective July 2, 1965, one year after passage of the entire Act. See id. at $\S 716($ a), 78 Stat. 253, 266. 
to treat the employee less favorably because of the employee's membership in a protected class. Alternatively, a plaintiff can allege disparate impact and argue that a facially neutral and objective employment practice, such as an aptitude test, has had a statistically significant adverse effect on members of a protected class, and as such is discriminatory absent a legitimate business justification. The circuit courts have disagreed over the proper approach to subjective decision-making. Yet whether a subjective practice is regarded as discriminatory depends largely on whether it is scrutinized under the disparate impact or disparate treatment standard. The differences in these approaches are substantial, both in terms of their theoretical underpinnings and, more importantly for plaintiffs, in terms of their respective allocation of evidentiary burdens. The approach which is used will often determine the outcome of a suit.

The Supreme Court recently addressed this issue in Watson $v$. Fort Worth Bank $\mathcal{E}^{2}$ Trust, ${ }^{2}$ a unanimous decision holding that discretionary decision-making by employers challenged as violating Title VII should be scrutinized under the disparate impact rather than the disparate treatment standard; thus, the question should be whether a facially neutral employment practice has had a statistically significant adverse effect on members of a minority group. Watson raises new and significant questions while failing to answer some old and persistent ones. This Comment argues that the Court was correct in choosing to apply disparate impact rather than disparate treatment analysis to subjective criteria. This decision was weakened, however, by the Court's failure to adequately justify its choice. This lack of a proper predicate lead the plurality in Watson to advance a new set of evidentiary burdens which, instead of strengthening disparate impact theory, would limit sharply its usefulness to plaintiffs in subjective criteria cases and could collapse disparate impact into disparate treatment analysis. .

This Comment seeks to provide the analytical framework necessary to set this inherently correct ruling on a firm footing and to enhance Watson's usefulness as a weapon against employment discrimination. The two basic approaches to Title VII claims and the unique issues presented by subjective employment practices are set forth in Part I. Part II examines the lower courts and Supreme Court Watson opinions. Part III discusses how subjective employment practices can be used as a vehicle for discrimination and explains why the disparate impact standard is a more effective way of policing such discrimination. Part IV critically examines the plurality's proposed allocation of the 
evidentiary burdens in subjective criteria cases. Arguing that the plurality's solution results from a failure to comprehend fully the challenges presented by subjective practices, Part V offers an alternative approach.

\section{Title VII Theories of Discrimination}

Title VII, as amended, ${ }^{3}$ broadly ${ }^{4}$ proscribes discrimination in employment on the basis of race, color, religion, sex, or national origin. ${ }^{5}$ Title VII regulates all aspects of the employment relationship and provides for only limited exceptions. ${ }^{6}$ Plaintiffs can prove employment discrimination in two ways: disparate treatment, which focuses on discriminatory intent, and disparate impact, which seeks to prove that a facially neutral employment practice has a statistically significant adverse effect on members of a protected class. ${ }^{7}$ Competing concepts of equality underlie these two frameworks. ${ }^{8}$ Disparate treatment seeks equality of opportunity and treatment. It emphasizes that race or other impermissible criteria should not be considered in employment decisions. Although such "color blindness" might help equalize job distribution between races, this result would be fortuitous. Disparate impact, on the other hand, seeks to attain equality of outcome or achievement.

3 Equal Employment Opportunity Act of 1972, Pub. L. No. 92-261, 86 Stat. 103 (1972) (codified as amendments to and deletions from 42 U.S.C. $\S 2000$ e to e-17 (1982)).

4 The scope of Title VII embraces all employers having fifteen or more employees. See 42 U.S.C. $\S 2000$ e(b) (1982).

Title VII provides that:

(a) ... It shall be an unlawful employment practice for an employer-

(1) to fail or refuse to hire or to discharge any individual, or otherwise to discriminate against any individual with respect to his compensation, terms, conditions, or privileges of employment, because of such individual's race, color, religion, sex, or national origin; or

(2) to limit, segregate, or classify his employees or applicants for employment in any way which would deprive or tend to deprive any individual of employment opportunities or otherwise adversely affect his status as an employee, because of such individual's race, color, religion, sex, or national origin.

42 U.S.C. § 2000e-2(a) (1982).

B The two most notable exceptions to the general prohibitions of Title VII encompass bona fide occupational qualifications, see 42 U.S.C. $\S 2000 \mathrm{e}-2(\mathrm{e})(1982)$, and bona fide seniority systems. See 42 U.S.C. $\S 2000 \mathrm{e}-2$ (h) (1982).

7 For an overview of these approaches, see B. Schlei \& P. Grossman, EMPloyMENT Discrimination Law 1-10 (2d ed. 1983 \& Supp. 1983-85); Corbett, Proving and Defending Employment Discrimination Claims, 47 MoNT. L. REv. 217, 217-62 (1986).

${ }^{8}$ See, e.g., Fallon \& Weiler, Firefighters v. Stotts: Conflicting Models of Racial Justice, 1984 SUP. CT. REv. 1, 10-26 (discussing the conflicting models of "individual" and "group" justice); Fiss, A Theory of Fair Employment Laws, 38 U. CHI. L. REv. 235, 237-40 (1971) (discussing the different conceptions of equality that underlie employment discrimination laws). 
The goal is not simply to compensate individual victims of specific acts of intentional discrimination, but rather to remedy the class-wide effects of racial injustice. Title VII plaintiffs may base their claim on either or both approaches and courts may apply one or the other in deciding a case. ${ }^{9}$ As the following discussion will demonstrate, marked differences in the proof requirements under each theory mean that the approach a court adopts can significantly affect the outcome of a Title VII suit.

\section{A. The Disparate Treatment Model}

The central issue in a disparate treatment case is whether the employer intended to treat an employee less favorably because of her race, color, religion, sex, or national origin. In McDonnell Douglas Corp. v. Green, ${ }^{10}$ the Supreme Court set forth the requirements for establishing a prima facie claim of disparate treatment:

The complainant in a Title VII trial must carry the initial burden under the statute of establishing a prima facie case of racial discrimination. This may be done by showing (i) that he belongs to a racial minority; (ii) that he applied and was qualified for a job for which the employer was seeking applicants; (iii) that, despite his qualifications, he was rejected; and (iv) that, after his rejection, the position remained open and the employer continued to seek applicants from persons of complainant's qualifications. ${ }^{11}$

Establishing a prima facie case is sufficient to create a rebuttable presumption of unlawful discrimination against the employer. The employer must respond by "producing evidence that the plaintiff was rejected, or someone else was preferred, for a legitimate, nondiscriminatory reason." 12 If the employer is successful, the pre-

( See International Bhd. of Teamsters v. United States, 431 U.S. 324, 335 n.15 (1977).

${ }_{10} 411$ U.S. 792 (1973). In McDonnell Douglas, a former employee who was a black civil rights activist sought reemployment after being laid off as a result of a general reduction in the work force. He alleged that he had been denied reemployment because of both his involvement in civil rights activities and his minority status. His former employer maintained that the plaintiff had not been rehired because he had engaged in unlawful activities against the firm in the process of protesting both his discharge and the firm's general hiring policies. See id. at 794-96.

${ }_{11} I d$. at 802. The Court noted, however, that this standard is flexible, as "[ $\left.t\right]$ he facts necessarily will vary in Title VII cases, and the specification above of the prima facie proof required from respondent is not necessarily applicable in every respect to differing factual situations." Id. at 802 n.13.

${ }_{12}$ Texas Dep't of Community Affairs v. Burdine, 450 U.S. 248, 254 (1981). The Court recognized that limiting the defendant's burden to one of mere production will not unduly hinder the plaintiff because: (1) the defendant's explanation of its legitimate 
sumption of discrimination raised by the prima facie case is rebutted and the plaintiff, who retains the burden of persuasion throughout the case, ${ }^{13}$ now has the opportunity to demonstrate through independent evidence that the employer's proffered reason was not the true reason for the employment decision, but was a mere pretext for an underlying discriminatory motive. ${ }^{14}$ This may be accomplished "either directly by persuading the court that a discriminatory reason more likely motivated the employer or indirectly by showing that the employer's proffered explanation is unworthy of credence."15

\section{B. The Disparate Impact Model}

Disparate impact occurs when facially neutral employment decision-making has a statistically significant and unjustifiable adverse effect on members of a protected class. Although such practices or criteria are not intentionally discriminatory, they perpetuate the effects of discrimination and are therefore invalid under Title VII. Disparate impact analysis was first authorized by the Supreme Court in Griggs $v$. Duke Power Co. ${ }^{16}$ which extended Title VII to practices which are "fair in form, but discriminatory in operation."17 In holding that the plaintiffs had established a prima facie case of discrimination, Chief Justice Burger, writing for a unanimous Court, declared that "good intent or absence of discriminatory intent does not redeem employment procedures or testing mechanisms that operate as 'built-in headwinds' for minority groups and are unrelated to measuring job capability."18

reason must be clear and reasonably specific, therefore affording the plaintiff a "full and fair opportunity" for rebuttal; (2) the defendant retains an incentive, although not a legal burden, to persuade the fact finder that the employment decision was valid, and in pursuit of this will provide the factual basis for its explanation; (3) liberal discovery rules and access to EEOC investigatory files will provide plaintiff with sufficient information to respond to the proffered reason. See id. at 258.

13 See id. at 253.

14 See id. at 256. In McDonnell Douglas, 411 U.S. at 807, the Court ultimately found that the employer had satisfied its burden of articulating a legitimate reason for its refusal to hire, but remanded the action so as to afford the former employee an opportunity to demonstrate that this explanation was pretextual.

${ }_{15}$ Burdine, 450 U.S. at 256.

18401 U.S. 424 (1971). In Griggs, black employees of a power plant challenged the employer's requirement that, as a condition of employment or transfer, employees either possess a high school diploma or obtain satisfactory scores on two standardized intelligence tests. The employees claimed that neither requirement was significantly related to job performance, both requirements operated disproportionately against blacks, and the jobs in question formerly had been filled only by whites as part of a long standing practice of giving preferential treatment to whites. There was no showing that the employer's requirements were intentionally discriminatory. See id. at 428 .

17 Id. at 431.

18 Id. at 432 . 
Proof of racial motive was not required because "Congress directed the thrust of the Act to the consequences of employment practices, not simply the motivation."io

To establish a prima facie case of discrimination under disparate impact, a plaintiff must show that the facially neutral criterion in question results in the hiring or promotion of applicants in a "significantly discriminatory pattern."20 The Supreme Court has approved three types of statistical comparisons for assessing the impact of an employer's practice on a protected group. ${ }^{21}$ "General population statistics" can be used to compare in a relevant geographic area the percentage of protected class members adversely affected by the employer's practice with the percentage of non-protected individuals similarly affected. Such data commonly are used when, due to a lack of specialized employment requirements, most of the population at large would be sufficiently qualified. ${ }^{22}$ "Applicant flow data" compares the minority composition of the pool of individuals applying for a job or promotion with the composition of those actually hired or promoted by the employer. Finally, the "available workforce statistic" compares the percentage of a protected class in the relevant labor market, defined as those individuals having the requisite skills for the job, with the percentage of that class in the employer's workforce. Which statistical population is used for comparison can determine whether or not a significant statistical disparity is shown.

To defend against such a showing, the employer must meet its burden of proving that the practice has a manifest relationship to the

19 Id. He added that "practices, procedures, or tests neutral on their face, and even neutral in terms of intent, cannot be maintained if they operate to 'freeze' the status quo of prior discriminatory employment practices." Id. at 430 .

20 Dothard v. Rawlinson, 433 U.S. 321, 329 (1977).

${ }^{21}$ See generally Norris, Statistical Proof and Theories of Discrimination, 49 Law \& ConTemp. Probs. 1 (1986); Waintroob, The Developing Law of Equal Employment Opportunity at the White Collar and Professional Level, 21 WM. \& MARY L. REv. 45, 69-86 (1979) (showing how the Supreme Court has accepted "general population," "available workforce," and "Applicant Flow and Internal" statistics as indicators of adverse impact).

${ }^{22}$ For example, in Hazelwood Sch. Dist. v. United States, 433 U.S. 299 (1977), the Court indicated that general population statistics had been appropriate in Teamsters "because the job skill there involved-the ability to drive a truck-is one that many persons possess or can fairly readily acquire. When special qualifications are required to fill particular jobs, [these statistics] may have little probative value." Id. at 308 n.13. Some commentators object to the use of general population data. See, e.g., Lerner, Employment Discrimination: Adverse Impact, Validity, and Equality, 1979 SUP. CT. REv. 17, 31-34, 38-39 (general population statistics are rarely in accord with the pool of qualified applicants because most jobs require qualifications not possessed by all adults; such statistics are never appropriate in Title VII cases). 
employment at issue; in effect, that its use was a business necessity. ${ }^{23}$ An employer may continue to use a criterion which has an adverse impact, regardless of its magnitude, on members of a protected group if that criterion is sufficiently job-related. ${ }^{24}$ Although the precise contours of this burden have been the subject of much debate, the courts clearly place upon the employer the burden of proving, not merely explaining, that a particular practice is warranted on the basis of business need. The plaintiff, however, may challenge this business necessity defense ${ }^{25}$ by showing that a less restrictive alternative is available that would meet the employer's legitimate needs and yet have less, if any, detrimental impact on minority group members. ${ }^{28}$

The Court has applied disparate impact to measure the effect of each component of a selection system, even if the impact of the overall system is not racially disproportionate. Thus, an employer cannot defend a showing of adverse impact by claiming the employment process as a whole does not operate in a discriminatory manner; a racially balanced "bottom line" will not suffice. ${ }^{27}$ Aside from this refinement, however, the scope of disparate impact analysis has remained uncertain.

${ }^{23}$ See Griggs, 401 U.S. at 432.

24 See Albemarle Paper Co. v. Moody, 422 U.S. 405, 431 (1975) ("[D]iscriminatory tests are impermissible unless shown . . . to be "predictive of or significantly correlated with important elements of work behavior which comprise or are relevant to the job or jobs for which candidates are being evaluated." (quoting Equal Employment Opportunity Commission Uniform Guidelines on Employee Selection Procedures, 29 C.F.R. § 1607.4(C) (1985) [hereinafter Uniform Guidelines])); see also B. Schlei \& P. Grossman, supra note 7, at 103-07 (same).

${ }^{25}$ One prominent commentator disputes the three-part procedure employed in evaluating traditional disparate impact claims, alleging that there is only one step in the analysis.

The employer's "defense" is actually a rebuttal of the plaintiffs" prima facie case, and the plaintiffs' attack on the "defense" is merely a further refinement of the prima facie case. In the end, the only question in adverse impact cases is whether an employment practice selects blacks and whites in numbers reasonably proportionate to the representations of the races in the available work force.

Gold, Griggs' Folly: An Essay on the Theory, Problems, and Origin of the Adverse Impact Definition of Employment Discrimination and a Recommendation for Reform, 7 INDUS. REL. L.J. 429, 433 (1985).

${ }^{28}$ See, e.g., Albemarle, 422 U.S. at 425 (plaintiff may "show that other tests or selection devices, without a similarly undesirable racial effect, would also serve the employer's legitimate interest in 'efficient and trustworthy workmanship.'" (quoting McDonnell Douglas Corp. v. Green, 411 U.S. 792, 801 (1973)).

${ }^{27}$ See Connecticut v. Teal, 457 U.S. 440, 442 (1982). The plaintiffs in Teal challenged Connecticut's promotion scheme for welfare supervisors which required that applicants first pass a written test. Statistics showed that more blacks than whites failed the test, but that actual promotions were awarded to blacks much more often than to whites. See id. at 444. The Court concluded that the employee's claim of discrimination should be analyzed under disparate impact and rejected the employer's asserted "bottom line" defense. See id. at 456. 
Until recently, ${ }^{28}$ Supreme Court decisions applying disparate impact involved objective or non-discretionary selection devices which were discrete and facially neutral. ${ }^{2 \theta}$ These decisions provided little guidance to lower federal courts asked to analyze an increasingly wide range of subjective employment practices under the disparate impact theory. ${ }^{30}$

\section{Disparate Impact and Subjective Criteria: Defining the Issue}

Courts have been reluctant to distinguish between "subjective" and "objective" employment criteria. ${ }^{31}$ The distinction, however, should not be dismissed lightly, as some courts and commentators tend to do, ${ }^{32}$

${ }^{28}$ See infra notes 43-100 and accompanying text.

29 The types of selection devices examined by the Court thus far include standardized intelligence tests (Griggs, 401 U.S. at 426; Albemarle, 422 U.S. at 409; Teal, 457 U.S. at 443), diploma requirements (Griggs, 401 U.S. at 425), minimum height and weight requirements (Dothard v. Rawlinson, 433 U.S. 321, 323-24 (1977)), and rules against the employment of drug users (New York Transit Auth. v. Beazer, 440 U.S. 568 (1979)). Cf. International Bhd. of Teamsters v. United States, 431 U.S. 324, 335 (1977) (applying disparate treatment in a Title VII challenge to uses of subjective practices in hiring and promotion); Hazelwood Sch. Dist. v. United States, 433 U.S. 299, 310-12 (1977) (same).

In Furnco Constr. Corp. v. Waters, 438 U.S. 567, 569 (1978), the Court declined to apply disparate impact analysis to a "grapevine" hiring system under which defendant's supervisor hired workers from a list of those whom he knew possessed the required skills for the position. In a controversial, albeit cryptic, footnote the Court stated that "[t]his case did not involve employment tests, which we dealt with in [Griggs] and in [Albemarle], or particularized requirements such as the height and weight specifications considered in [Dothard], and it was not a 'pattern or practice' case like [Teamsters]." Id. at $575 \mathrm{n} .7$ (citations omitted). This has been interpreted by some as a limitation on the type of employment practices to which disparate impact analysis is appropriately applied, namely those which the Court has scrutinized already. See, e.g., 3 A. LARSON \& L. LarSon, EMployment Discrimination $§ 76.32$, at 15-85 (1986 \& Supp. 1988) (citing the impossibility of validation and the conceptual distinction between disparate impact and disparate treatment as reasons for limiting impact analysis to objective procedures). For the most part, however, this offhand statement has been ignored by lower courts, as is shown by their application of disparate impact to practices supposedly outside this sphere. See infra note 32; see also Furnco, 438 U.S. at 583-85 (Marshall, J., dissenting).

so See Comment, Applying Disparate Impact Theory to Subjective Employee Selection Procedures, 20 LOY. L.A.L. REv. 375, 376 n.8 (1987) (describing the staggering volume of Title VII complaints-approximately fifty-four thousand in 1983 alone).

${ }_{31}$ See, e.g., Griggs, 401 U.S. 424; Albemarle, 422 U.S. 405; Dothard, 433 U.S. 321; Teal, 457 U.S. 440; see also Rigler, Title VII and the Applicability of Disparate Impact Analysis to Subjective Selection Criteria, 88 W. VA. L. REv. 25, 33 (1985) ("Each decision has employed a method reminiscent of Justice Stewart's memorable concurrence regarding pornography: 'I know it when I see it." "). Certainly a pragmatic reason for concluding that disparate impact applies to subjective as well as objective criteria is that doing so avoids the task of investigating the differences between them. See id. at 45.

32 See, e.g., Atonio v. Wards Cove Packing Co., 810 F.2d 1477, 1485 (9th Cir. 1987) ("[W]e think a distinction between subjective and objective serves no legitimate purpose . . . ."), cert. granted in part, 108 S. Ct. 2896 (1988); Rigler, supra note 31, 
since it is at the heart of a proper understanding of how these respective criteria are to be scrutinized under Title VII.

Objective criteria typically include examinations, education requirements, work experience, or licensing requirements. Such criteria are neutral, are applied mechanically and without exception to all applicants, and leave little or no room for the use of discretion. ${ }^{33}$ The ease with which the consequences of objective criteria can be expressed statistically makes them particularly amenable to disparate impact analysis.

By contrast, subjective ${ }^{34}$ criteria allow for the use of discretion by the decisionmaker. ${ }^{95}$ An employer making a subjective decision will draw on her perspectives, beliefs, experience, and judgment. Discretionary criteria are standardless in the sense that there is no identifiable external standard by which they can be measured. Consequently, the application of subjective devices is characterized by a lack of uniformity.

There are many kinds of subjective selection devices. The most common include interviews, performance appraisals not based on "hard" data such as quantifiable attendance or production records, nepotism, and the use of "grapevine" hiring or promotion systems which selectively announce job openings. Such devices are used most commonly in the making of promotion and termination decisions rather than at the initial hiring stage because at these later stages there is more information on which a subjective decision can be based. ${ }^{36} \mathrm{~A}$ se-

at 27 ("[T]here is no logical reason for distinguishing between subjective and objective criteria. The heart of disparate impact analysis under Title VII is facial neutrality ....").

ss "Objective" is defined as "expressing or involving the use of facts without distortion by personal feelings or prejudices." WEBSTER'S THIRD NEw INTERNATIONAL DICTIONARY 1556 (1981).

34 "Subjective" is defined as "peculiar to a particular individual modified by individual bias and limitations; personal." Id. at 2275-76.

ss See Uniform Guidelines, supra note 24, $\S 1607.6(\mathrm{~b})(1)$ (referring to subjective criteria as "informal or unscored" procedures); Waintroob, supra note 21 , at 48 (subjective procedures are those in which "judgment or discretion [is exercised] on the part of the evaluator"). For a general discussion of the characteristics of subjective employment practices, see B. SchleI \& P. Grossman, supra note 7, at 191-205.

${ }^{38}$ For an excellent discussion of the definition and use of subjective criteria, see Blumrosen, The Legacy of Griggs: Social Progress and Subjective Judgments, 63 CHI.KENT L. REv. 1, 17-23 (1987). In particular, Blumrosen identifies an increase in the use of subjective criteria and attributes this to five factors: (1) the Supreme Court's decision in Griggs; (2) the declining adherence to the older theory of "scientific management" which defined jobs in terms of repetitive performance of limited functions; (3) the shift from "smoke stack to service industries" and from blue collar to white collar work, both of which require developed interpersonal skills and other intangible abilities; (4) the existence of "upper tier" jobs which require the employee to engage in decision-making under conditions of uncertainty; (5) the increase in reorganizations, 
lection system that uses a mix of objective and subjective criteria ${ }^{37}$ will likely be considered subjective, as will a system that relies exclusively on objective factors but neglects to assign weights to the various factors. $^{38}$

Prior to Watson, the characterization of a selection system as either objective or subjective was significant since courts differed as to which theory of discrimination should be applied to subjective employment decisions. The Fifth Circuit's use of disparate impact analysis in Rowe v. General Motors Corp. ${ }^{39}$ was followed for nearly a decade. ${ }^{40}$ This consistency, however, was disrupted in the early 1980 s when the Fifth and Ninth Circuits scrutinized discretionary employment practices under disparate treatment. ${ }^{41}$ Since this initial disagreement, the Federal Courts of Appeals have continued to differ as to whether disparate impact analysis is properly applied to subjective employment criteria. ${ }^{42}$ This issue finally was resolved by the Supreme Court in Watson.

mergers, and acquisitions which has placed pressures on managers to pay closer attention to the quality of the employees they select, causing them to favor those whose background is similar to their own. See id. To this list, a sixth factor may be added: the costly and time consuming process of validation which objective employment practices must undergo in order to withstand Title VII challenges have caused employers to rely more heavily on subjective criteria. See, e.g., Gold, supra note 25, at 587 (the cost of developing job related criteria may exceed the benefits in using them); Lerner, supra note 22 , at $18 \&$ n. 6 (noting that scientific validation is expensive, time-consuming, and difficult).

37 A typical system, such as that at issue in Griggs v. Duke Power Co., 401 U.S. 424, 427-28 (1971), may require that applicants possess a high school diploma, take a standardized aptitude test and be interviewed by a member of the personnel department or the manager of the department in which the applicant seeks to work.

38 See Hung Ping Wang v. Hoffman, 694 F.2d 1146, 1149 (9th Gir. 1982); Blumrosen, supra note 36, at 23-24.

so 457 F.2d 348 (5th Cir. 1972).

40 See James v. Stockham Valves \& Fittings, Inc., 559 F.2d 310, 330 (5th Cir. 1977), cert. denied, 434 U.S. 1034 (1978); Senter v. General Motors Corp., 532 F.2d 511, 528-30 (6th Gir.), cert denied, 429 U.S. 870 (1976); Stewart v. General Motors Corp., 542 F.2d 445, 450-51 (7th Cir.), cert. denied, 433 U.S. 919 (1976), reh'g denied, 434 U.S. 881 (1977); Muller v. United States Steel Corp., 509 F.2d 923, 928 (10th Cir.), cert. denied, 423 U.S. 825 (1975).

${ }^{41}$ In Heagney v. University of Washington, 642 F.2d 1157, 1163 (9th Gir. 1981), the Ninth Circuit held that the university's practice of categorizing non-academic employees as either "classified" or "exempt" was not an objective practice. Consequently, disparate impact analysis was held to be inappropriate because subjective employment practices must be shown to be intentionally discriminatory under disparate treatment. Similarly, in Pouncy v. Prudential Ins. Co., 668 F.2d 795, 800 (5th Cir. 1982), the Fifth Circuit refused to allow a disparate impact challenge to the cumulative effects of a promotion scheme composed of both subjective and objective elements.

12 The Second, Third, Sixth, Ninth, Tenth, Eleventh, and District of Columbia Circuits have applied disparate impact analysis to subjective systems. See, e.g., Atonio v. Wards Cove Packing Co., 810 F.2d 1477, 1480-81 (9th Cir. 1987) (en banc), cert. granted in part, 108 S. Ct. 2896 (1988); Hawkins v. Bounds, 752 F.2d 500, 503 (10th Cir. 1985); Griffin v. Garlin, 755 F.2d 1516, 1522-26 (11th Gir. 1985); Maddox v. 


\section{THE Watson Decision}

\section{A. The District Court's Disparate Treatment Analysis}

In Watson, the Court was presented with a typical selective judgment case under Title VII. The plaintiff, Clara Watson, was a black employee of Fort Worth Bank \& Trust (the "Bank") who had applied, and been turned down, for a number of promotions. ${ }^{43}$ In her class ac-

Claytor, 764 F.2d 1539, 1548 (11th Cir. 1985); Segar v. Smith, 738 F.2d 1249, 1266, 1270-72 (D.G. Cir. 1984), cert. denied, 471 U.S. 1115 (1985); Zahorik v. Cornell Univ., 729 F.2d 85, 95-96 (2d Gir. 1984); Lasso v. Woodmen of the World Life Ins. Co., 741 F.2d 1241, 1244 (10th Cir. 1984), cert. denied, 471 U.S. 1099 (1985); Eastland v. Tennessee Valley Auth., 704 F.2d 613, 619-20 (11th Cir. 1983), cert. denied, 465 U.S. 1066 (1984); Wilmore v. City of Wilmington, 699 F.2d 667, 672-74 (3d Cir. 1983); Moore v. Hughes Helicopters, Inc., 708 F.2d 475, 481-82 (9th Gir. 1983); Rowe v. Cleveland Pneumatic Co., 690 F.2d 88, 93-95 (6th Cir. 1982); Hung Ping Wang, 694 F.2d at 1147-48; Williams v. Colorado Springs Sch. Dist., 641 F.2d 835, 842 (10th Cir. 1981); Grant v. Bethlehem Steel Corp., 635 F.2d 1007, 1016 (2d Cir. 1980), cert. denied, 452 U.S. 940 (1981).

The Fifth Circuit has analyzed subjective practices under disparate treatment. See, e.g., Watson v. Fort Worth Bank \& Trust, 798 F.2d 791, 797-98 (5th Cir. 1986), vacated, 108 S. Ct. 2777 (1988); Walls v. Mississippi State Dep't of Pub. Welfare, 730 F.2d 306, 321-22 (5th Cir. 1984); Pegues v. Mississippi State Employment Serv., 699 F.2d 760, 765 (5th Cir.), cert. denied, 464 U.S. 991 (1983).

The Fourth, Seventh, and Eighth Circuits are split internally. Compare EEOC v. Federal Reserve Bank, 698 F.2d 633, 639 (4th Cir. 1983) (using disparate impact to scrutinize subjective criteria), rev'd on other grounds sub nom., Cooper v. Federal Reserve Bank, 467 U.S. 867 (1984) and Pope v. City of Hickory, 679 F.2d 20, 22 (4th Gir. 1982) (same) with Brown v. Gaston County Dyeing Mach. Go., 457 F.2d 1377, 1382 (4th Cir.), cert. denied, 409 U.S. 982 (1972) (focusing on practices and general policies instead of disparate impact analysis); compare Regner v. City of Chicago, 789 F.2d 534, 539 (7th Cir. 1986) (allowing a disparate impact claim despite the existence of subjective elements) and Clark v. Chrysler Corp., 673 F.2d 921, 926-27 (7th Cir.) (same), cert. denied, 459 U.S. 873 (1982) with Griffin v. Board of Regents of Regency Univ., 795 F.2d 1281, 1288 (7th Cir. 1986) (denying a disparate impact claim because plaintiffs could not identify a neutral criterion); compare EEOC v. Rath Packing Co., 787 F.2d 318, 327-28 (8th Cir.) (applying disparate impact analysis to subjective criteria), cert. denied, 107 S. Ct. 307 (1986) and Hutto v. Jones, 763 F.2d 979, 983-84 (8th Gir.) (same), vacated, 474 U.S. 916 (1985) with Talley v. United States Postal Serv., 720 F.2d 505, 506-08 (8th Cir.) (refusing to apply disparate impact analysis unless there exists some facially neutral practice), cert. denied, 466 U.S. 952 (1984) and Taylor v. Teletype Corp., 648 F.2d 1129, 1132 n.6 (8th Cir.) (same), cert. denied, 454 U.S. 969 (1981).

The First Circuit has not yet been faced with the issue. See Latinos Unidos de Chelsea en Accion v. Secretary of Hous. \& Urban Dev., 799 F.2d 774, 786 (1st Gir. 1986) ("We again find it unnecessary to decide whether the disparate impact model ever may be used in a case involving subjective criteria."); Robinson v. Polaroid Corp., 732 F.2d 1010, 1014 (1st Cir. 1984)(same).

43 See Watson v. Fort Worth Bank \& Trust, 108 S. Ct. 2777 (1988). Hired in 1973 as a proof operator, Watson was promoted subsequently to teller in the Bank's motor bank, and then in 1980 to commercial teller in the Bank's main lobby. On four separate occasions during the following year, Watson was turned down for promotions to supervisory positions. First, she sought the position of teller supervisor; the position was awarded, however, to a white male. She then applied to be motor bank teller 
tion, Watson alleged that the Bank had discriminated unlawfully against her and other blacks in hiring, initial placement, compensation, promotion, termination, and other terms and conditions of employment. ${ }^{44}$ She relied on both the disparate impact and disparate treatment theories. ${ }^{45}$

The Bank relied exclusively on its white supervisors to make hiring and promotion decisions in their respective departments. ${ }^{46}$ No written criteria were used by these supervisors in evaluating employees for hiring or promotion purposes. Instead, employees were given supervisory ratings based on twelve factors: accuracy of work, alertness, personal appearance, relations with supervisors and co-workers, quantity of work, physical fitness, attendance, dependability, stability, drive, friendliness and courtesy, and job knowledge. ${ }^{47}$ The resulting score was combined with "other factors" deemed appropriate by the supervisor and then used to select candidates for promotion. ${ }^{48}$

The district court found, using disparate treatment analysis, that the Bank had not violated Title VII. ${ }^{49}$ The court analyzed Watson's individual claim under the McDonnell Douglas ${ }^{50}$ and Burdine $e^{51}$ disparate treatment model. ${ }^{52}$ Watson succeeded in establishing a prima facie

supervisor, but the job was given to a white female. Later, Watson again sought to become supervisor of the lobby tellers, but was rejected a third time in favor of a white female. Finally, when the position of supervisor of the motor bank tellers again became vacant, Watson applied but was rejected in favor of a white male teller. Watson subsequently resigned in August of 1981. See id. at 2782. When Watson filed suit, the Bank had almost eighty employees; it had never employed a black supervisor, director or bank officer. See Watson, 798 F.2d at 808 (Goldberg, J., dissenting). Watson demonstrated that she had been with the Bank longer than two of the white employees selected over her for promotions and that she possessed more supervisory experience than another successful candidate. See id. at 793 \& n.1, 794 nn.1 \& 2.

14 See id. at 794, 797.

15 See id. at 806 n.12 ("Watson advances both her individual and class claims under a theory of disparate treatment ...."). When Watson's initial disparate treatment claims were denied, she turned to impact analysis. See Brief for Petitioner at 8, Watson v. Fort Worth Bank \& Trust Co., 108 S. Ct. 2777 (1988) (No. 86-6139).

${ }^{16}$ See Watson, 798 F.2d at 805-06. Although a senior vice president had final authority over all personnel matters, as a general rule he deferred to the supervisors' judgment. Also, although a committee was charged with approving all salary increases, those increases were based on the results of supervisory performance evaluations, and these results rarely were disturbed. See id.

47 See id. at 812 n.26 (Goldberg, J., dissenting).

48 See id. at 811-13 (Goldberg, J., dissenting).

49 See Watson v. Fort Worth Bank \& Trust, No. 4-81-581-E, slip op. at 9, 14 (N.D.Tex. Nov. 21, 1984) [hereinafter Watson slip op.].

so McDonnell Douglas Corp. v. Green, 411 U.S. 292 (1973); see supra notes 1015 and accompanying text.

51 Texas Dep't of Community Affairs v. Burdine, 450 U.S. 248 (1981); see supra notes 12-15 and accompanying text.

${ }^{62}$ See Watson slip op., supra note 49, at 195-96. 
case of discrimination; ${ }^{53}$ nevertheless, the district court found persuasive the legitimate, non-discriminatory reasons asserted by the Bank for each disputed promotion. ${ }^{54}$ Since Watson failed to demonstrate that the reasons proffered by the Bank were a mere pretext for discriminatory conduct, the district court ultimately held that Watson had not been the victim of intentional discrimination. ${ }^{\text {ss }}$

With regard to the claims of the applicant class, the court found that the statistical evidence provided by Watson failed to establish a prima facie pattern and practice of discriminatory hiring. ${ }^{56}$ In so finding, the court relied on general population figures indicating that blacks represented 13.1 percent of the defendant's workforce, which compared to 10.2 percent of the population in the Fort Worth metropolitan area and 11.8 percent of the Tarrant County population. ${ }^{67}$

The district court failed to articulate its rationale for preferring general population statistics to the applicant flow data presented by Watson, which showed that only a small proportion of blacks who applied were actually hired by the Bank. During a four-year period, 4.2 percent of blacks who applied were offered positions, as opposed to 16.7 percent of whites. ${ }^{58}$ In addition, in a period covering four annual evaluations, black employees scored an average of eleven to fifteen points lower than their non-black co-workers ${ }^{59}$ and black employees were paid $\$ 45.98$ per month less than similarly situated co-workers. ${ }^{60}$ These disparities in hiring, evaluation, and compensation were statistically significant. ${ }^{61}$

Following affirmation by the Fifth Circuit of the ruling on plaintiff's individual claim of discrimination, ${ }^{62}$ the Supreme Court granted a

ss See id. at 196.

54 Such reasons included excellent performance ratings, a high level of education and the ability to get along with fellow workers. See id. at 196-97.

ss See id. at 197.

${ }^{86}$ See id. at 15.

B7 See id.

s8 See Watson v. Fort Worth Bank \& Trust, 798 F.2d 791, 810-11 (Goldberg, J., dissenting).

so See id. at 812-13 \& n.27 (Goldberg, J., dissenting).

${ }^{60}$ See id. at 813 \& n.30 (Goldberg, J., dissenting).

61 See id. at 810 (Goldberg, J., dissenting) (emphasizing that "two or three standard deviations constitutes sufficient statistical proof').

${ }^{62}$ A divided Fifth Circuit declined to apply disparate impact analysis to the Bank's subjective promotion process. See id. at 797. While the court said it would have applied disparate impact if the matter had been one of first impression, the panel noted that it was required by its earlier decision in Pouncy v. Prudential Ins. Co., 668 F.2d 795,800 (5th Cir. 1982), to apply disparate treatment analysis to the plaintiff's claims. See Watson, 798 F.2d at 797 n.12. The Fifth Gircuit also remanded the action for dismissal of the applicant class claims without prejudice. See id. at 799. 
writ of certiorari ${ }^{63}$ to resolve a long-standing division among the circuits by determining whether disparate impact analysis may be applied to subjective employment practices.

\section{B. The Supreme Court's Disparate Impact Analysis}

In a unanimous decision, ${ }^{64}$ the Supreme Court held that subjective selection practices challenged as violating Title VII may be subject to disparate impact analysis. ${ }^{65}$ The Court, in an opinion by Justice O'Connor, recognized at the outset that despite the substantially different evidentiary standards employed, disparate treatment and disparate impact are united in serving a common purpose:

The distinguishing features of the factual issues that typically dominate in disparate impact cases do not imply that the ultimate legal issue is different than in cases where disparate treatment analysis is used. . . . Rather, the necessary premise of the disparate impact approach is that some employment practices, adopted without a deliberately discriminatory motive, may in operation be functionally equivalent to intentional discrimination. ${ }^{66}$

Given this starting point, the Court furnished two principle rationales for its decision. First, the Court was persuaded that if disparate impact analysis was confined to objective decision-making, its landmark decision in Griggs ${ }^{67}$ would "become a dead letter." favorable evidentiary requirements imposed by disparate impact, an employer simply could introduce a single subjective component into its decision-making process since, as the Court noted, "[h]owever one might distinguish 'subjective' from 'objective' criteria, it is apparent that selection systems that combine both types would generally have to be considered subjective in nature." Such an incentive would contravene the purposes of Title VII. ${ }^{70}$ Employers could give subjective criteria

es 107 S. Ct. 3227 (1987).

at Justice Anthony Kennedy did not participate in the consideration or decision. See Watson v. Fort Worth Bank \& Trust, 108 S. Ct. 2777, 2777, 2791 (1988).

${ }^{65}$ See id. at 2787. The Court vacated the Fifth Circuit's ruling and remanded the action to the district court to determine whether plaintiff's statistical evidence was sufficient to make out a prima facie case under disparate impact theory. See id. at 2791.

${ }^{68} I d$. at 2785 (citation omitted).

67 Griggs v. Duke Power Co., 401 U.S. 424 (1971); see also supra notes 16-19 and accompanying text (discussing the Court's first authorization of disparate impact analysis).

es Watson, 108 S. Ct. at 2786.

69 Id.

70 See Griffin v. Carlin, 755 F.2d 1516, 1525 (11th Cir. 1985) (using the "im- 
substantial but not absolute weight, and so avoid the strictures of disparate impact. ${ }^{71}$ Discriminatory intent could be more easily masked thereby, ${ }^{72}$ and more difficult for a plaintiff to establish. ${ }^{73}$ To circumvent this "stark and uninviting" alternative, ${ }^{74}$ the Court extended disparate impact to subjective employment practices.

As a second justification, Justice O'Connor emphasized that applying disparate impact to subjective decisions was warranted because the same factors which pointed to its use in objective cases were also persuasive in subjective cases. ${ }^{75}$ Neutral employment practices-whether subjective or objective-can have a discriminatory effect $^{76}$ and are therefore equivalent to practices that are facially discrim-

proper incentive" rationale to justify applying disparate impact analysis to a largely subjective promotion system).

${ }^{71}$ See, e.g., Blumrosen, supra note 36 , at 17-20 (identifying an increase in the use of subjective criteria and suggesting this was partly due to employers attempting to avoid the disparate impact analysis of objective criteria authorized by Griggs).

${ }_{72}$ See Comment, Disparate Impact and Subjective Employment Criteria Under Title VII, 54 U. CHI. L. REv. 957, 970 (1987) (recognizing that if disparate impact is limited to objective employment practices, "[t]hose employers intending to discriminate can do so more easily, while even those without bad intentions will tend to shy away from objective criteria whose impact might later be attacked").

${ }^{73}$ See Watson, 108 S. Ct. at 2786 ("If we announced a rule that allowed employers so easily to insulate themselves from liability under Griggs, disparate impact analysis might effectively be abolished."); infra notes 102-12 and accompanying text.

${ }_{74}$ Watson, $108 \mathrm{~S}$. Ct. at 2786.

75 "We are also persuaded that disparate impact analysis is in principle no less applicable to subjective employment criteria than to objective or standardized tests." Id. at 2786. This "equivalence" theme occurred throughout Justice O'Connor's opinion. See also D. Baldus \& J. Cole, Statistical Proof of Discrimination $\S 1.23$ (Supp. 1987).

[I]n terms of the goal of adverse impact doctrine, there is no basis for distinguishing between the effects of objective and subjective selection criteria. First, it is sometimes difficult to distinguish between "objective" and "subjective" selection criteria. But more importantly, in terms of their potential adverse impact on employment opportunities for minorities and women, there is no principled basis for distinguishing between the two types of criteria.

Id.

${ }^{78}$ According to the Court, a facially neutral practice may have effects which are "indistinguishable from intentionally discriminatory practices." Watson, $108 \mathrm{~S}$. C. at 2786 (emphasis added). Justice O'Connor seems to have set up a dichotomy between unintentional discriminatory acts, whether accomplished via subjective or objective selection devices, that should be scrutinized under disparate impact, and acts of intentional discrimination subject to disparate treatment. The Court thereby implies without justification that subjective criteria should be within the scope of Griggs because they can be used as a vehicle for unintentional discrimination. Unfortunately, by repeatedly emphasizing that Title VII's proscription applies not only to intentional discrimination, but also to neutral acts having the same effect, Justice O'Connor failed adequately to explain how subjective devices are different and why disparate treatment analysis is not an effective way of policing their use. See infra notes 94-135 and accompanying text. By lumping together subjective and objective criteria, the Court has avoided the heart of 
inatory. Although discretionary decision-making is not per se unlawful discrimination, ${ }^{77}$ some supervisors in fact act may with discriminatory intent. Even more importantly for the Court, subjective decision-making can facilitate discrimination by providing an outlet for subconscious racial stereotypes and prejudices. ${ }^{78}$ The Court thus seems implicitly to have acknowledged that the chief threat posed by subjective employment practices is that they can be a vehicle for unintentional discrimination. ${ }^{79}$ Characterizing subjective practices this way requires that they be scrutinized using disparate impact analysis.

\section{The Allocation of Evidentiary Burdens}

Having applied disparate impact analysis to subjective decisionmaking, Justice O'Connor, now supported only by a plurality consisting of Chief Justice Rehnquist and Justices White and Scalia, addressed the evidentiary standards that should apply in such cases. ${ }^{80}$ Of primary concern to the plurality was whether extending disparate impact analysis to subjective criteria would induce employers to adopt quotas in selection and promotion decisions. ${ }^{\mathbf{8 1}}$ Disparate impact permits

the debate: whether and, more importantly, why the disparate impact approach should be applied to subjective employment practices.

${ }_{77}$ According to the Court,

[A]n employer's policy of leaving promotion decisions to the unchecked discretion of lower level supervisors should itself raise no inference of discriminatory conduct. Especially in relatively small businesses like respondent's, it may be customary and quite reasonable simply to delegate employment decisions to those employees who are most familiar with the jobs to be filled and with the candidates for those jobs.

Watson, 108 S. Ct. at 2786.

${ }_{78}$ The sole support provided by Justice O'Connor for this assertion was an example from Watson. When she first applied for the teller position, Watson was told that the job was a big responsibility, and that there would be " a lot of money . . . for blacks to have to count." Id. at 2786 (quoting Joint Appendix at 7, Watson v. Fort Worth Bank \& Trust, 108 S. Ct. 2777 (1988) (No. 86-6139)). This statement however, could be regarded as a clear-cut instance of intentional, rather than unintentional, discrimination. It is reminiscent of the evidence presented by plaintiffs in decisions such as Slack v. Havens, 7 Fair Empl. Prac. Cas. (BNA) 885, 889 (S.D. Cal. July 17, 1973) (statements by supervisor that "colored folks were hired to clean because they cleaned better" and "colored folks should stay in their place" were direct evidence of discriminatory intent), affd and remanded, 522 F.2d 1091 (9th Cir. 1975).

${ }_{70}$ See Watson, $108 \mathrm{~S}$. Gt. at 2786 ("Such remarks may not prove discriminatory intent, but they do suggest a lingering form of the problem that Title VII was enacted to combat."). Whether intentional or unintentional, discrimination has the same effect on the individual employee and it is this effect that Title VII is designed to obviate.

${ }^{80}$ See id. at 2787-91.

81 See id.; see also Connecticut v. Teal, 457 U.S. 440, 463 (1982) (Powell, J., dissenting) ("[The result of forcing] employers either to eliminate tests or rely on expensive, job-related testing procedures, the validity of which may or may not be sustained if challenged, . . . may well be the adoption of simple quota hiring."); Gold, 
the plaintiff to establish a prima facie case with statistical evidence. The employer then must persuade the court that either the disparity does not exist or that it is due to the use of a criterion justified by business necessity. ${ }^{82}$ Although this rebuttal burden may be met easily when the criteria are objective since standardized tests, for example, may be validated without undue difficulty ${ }^{83}$ the situation becomes more onerous for an employer when subjective criteria are at issue. ${ }^{84}$ Since validation is too impractical, too costly, and too time-consuming, the argument runs, employers will institute quotas in order to prevent a plaintiff from using employment decision statistics to establish a prima facie case. ${ }^{85}$ The plurality sympathized with employers, acknowledging

supra note 25, at 587-88 (arguing that adverse impact has encouraged employers to resort to quota hiring in an effort to avoid liability).

${ }_{82}$ See supra notes 23-24 and accompanying text.

${ }^{83}$ See Uniform Guidelines, supra note $24, \S \S 1607.5$ to $-.9,1607.14$ (providing a rather elaborate framework for validation); see also Detroit Edison Co. v. NLRB, 440 U.S. 301, 305-06 \& n.4 (1979) (discussing the empirical method of validation by which employers can demonstrate a correlation between test scores and job performance); Albemarle Paper Co. v. Moody, 422 U.S. 405, 425-36 (1975) ("job relatedness" will validate standardized tests); Waintroob, supra note 21, at 62-63 (stating that in the white collar context, employers easily have shown the validity of standardized tests). But see Gold, supra note 25 , at 459 (stating that "few existing tests can be validated against the standards in the EEOC Guidelines").

B4 The ease with which subjective devices may be validated is a question which has sparked much debate. Compare Rutherglen, Disparate Impact Under Title VII: An Objective Theory of Discrimination, 73 VA. L. REV. 1297, 1330 (1987) (defendants have little "realistic prospect of validating subjective selection procedures with adverse impact") and Note, Evaluation of Subjective Selection Systems in Title VII Employment Discrimination Cases: A Misuse of Disparate Impact Analysis, 7 Gardozo L. REv. 549, 578 (1986) (in order for employers to validate subjective hiring systems, they must "justify each and every qualification as a business necessity") with Atonio v. Ward's Cove Packing Co., 810 F.2d 1477, 1486 (9th Cir. 1987) (en banc) (holding that imposing upon the employer the burden of proving the business necessity of a subjective practice was not unduly onerous because such a burden was commensurate with the plaintiff's task in proving her prima facie case; furthermore, the employer, rather than the plaintiff, was in a unique position as the party most knowledgeable concerning the purposes and effects of its selection practices), cert. granted in part, 108 S. Ct. 2896 (1988) and Brief for Amicus Curiae in Support of Petitioner by the American Psychological Association at 2, Watson v. Fort Worth Bank \& Trust, 108 S. Ct. 2777 (1988) (No. 86-6139) ("Subjective selection devices can be scientifically validated for the assessment of individuals for hiring, promotion, or other selection decisions in the employment context.") and Shoben, Probing the Discriminatory Effects of Employee Selection Procedures with Disparate Impact Analysis Under Title VII, 56 TEx. L. REv. 1, 34-36 (1977) (suggesting that employers can validate their systems by showing favorable hiring data and application flow data).

8s The plurality sided with those who argue that it is difficult to validate subjective criteria. Subjective criteria are necessary since many jobs require qualities or skills which cannot be measured objectively. Whether an employee so selected has been an employment success cannot be determined directly, so neither can the predictive validity of the subjective criteria. Thus, subjective selection criteria are "impossible to eliminate" and "impossibly expensive to defend." Watson, $108 \mathrm{~S}$. Ct. at 2787. But see Atonio, 810 F.2d at 1486 (holding that imposing upon the employer the burden of 
that the Bank was "correct when [it] argue[d] that extending disparate impact analysis to subjective employment practices has the potential to create a Hobson's choice for employers and thus to lead in practice to perverse results." 86

Extending disparate impact also raises the fear of broad "cumulative effects" challenges to complex employee selection systems. Most employers evaluate applicants on the basis of mixed subjective and objective criteria. ${ }^{87} \mathrm{~A}$ plaintiff bringing a Title VII suit under disparate impact would allege a statistically significant disparity, broadly contending that the employer's hiring system as a whole is discriminatory. An employer relying on mixed criteria thus would have to isolate and justify each criterion, comparing its effect on the plaintiff with its effect on the protected group as a whole. ${ }^{88}$ Given the potential problems with validating subjective criteria, ${ }^{\mathbf{8 9}}$ this could be a particularly difficult task to complete.

Justice O'Connor responded to these fears by articulating two evidentiary safeguards. ${ }^{90}$ The first of these relates to the nature of the plaintiff's prima facie case, addressing the problems posed by broadbased attacks on an employer's selection system. Justice O'Connor held that when challenging subjective practices under disparate impact, a

proving the business necessity of subjective practice was not unduly onerous, as such a burden was commensurate with the plaintiff's task in proving her prima facie case; furthermore, the employer, rather than the plaintiff, was in a unique position as the party most knowledgeable concerning the purposes and effects of its selection practices).

se Watson, $108 \mathrm{~S}$. Cit. at 2788.

87 See supra note 37 and accompanying text.

88 Such fears of an employer's burden were raised by the Fifth Circuit in Pouncy v. Prudential Ins. Co., 668 F.2d 795, 800-01 (5th Cir. 1982). The court would "not permit a plaintiff to challenge an entire range of employment practices merely because the employer's work force reflects a racial imbalance that might be causally related to any one or more of several practices . . . ." Id. at 801 . Instead, the plaintiff was required to provide "proof that a specific practice results in a discriminatory impact . . . in order to allocate fairly the parties' respective burdens of proof at trial." Id. at 800 . This added burden on the plaintiff was justified because it was unfair to place on the defendant "the dual burden of articulating which of its employment practices cause the adverse impact at issue and proving the business necessity of the practice." Id. Similar concerns prompted the Ninth Circuit in Atonio, 810 F.2d at 1477, to require the plaintiff to "identify specific employment practices or selection criteria" as part of the three elements composing a prima facie case under disparate impact. $I d$. at 1482.

Some have argued that this identification requirement is unnecessary. See, e.g., Rigler, supra note 31, at 35-36 (arguing that an employer will not find itself in the unfavorable position of defending its entire selection system once a prima facie case is established because the employer controls what practice or practices to identify as the cause of the disparity); Comment, supra note 72, at 974-76 (suggesting that the burden on the employer would not be unfair; the employer would not have to isolate the effects of specific practices as long as it proved that all the criteria met the business necessity test).

89 See supra notes 85-86 and accompanying text.

${ }^{80}$ See Watson, $108 \mathrm{~S}$. C. at 2788-91. 
"plaintiff must begin by identifying the specific employment practice that is challenged." "sometimes be more difficult" when subjective, rather than objective, selection criteria are at issue. ${ }^{92}$ Once this task has been accomplished, the plaintiff must establish causation by offering "statistical evidence ... sufficient to show that the practice in question has caused the exclusion of applicants for jobs or promotions because of their membership in a protected group." ${ }^{\text {93 }}$

The second constraint concerns the nature of an employer's rebuttal burden, thus addressing the Court's fear that scrutinizing subjective criteria under disparate impact analysis would provide employers with an incentive to institute quotas. After reemphasizing that the employer has " "the burden of showing that any given requirement must have a manifest relationship to the employment in question," "94 the plurality unexpectedly reduces the employer's burden from one of persuasion to one of production:

Although we have said that an employer has "the burden of showing that any given requirement must have a manifest relationship to the employment in question," such a formulation should not be interpreted as implying that the ultimate burden of proof can be shifted to the defendant. On the contrary, the ultimate burden of proving that discrimination against a protected group has been caused by a specific employment practice remains with the plaintiff at all times. Thus, when the plaintiff has made out a prima facie case of disparate impact, and when the defendant has met its burden of producing evidence that its employment practices are based on legitimate business reasons, the plaintiff must "show that other tests or selection devices, without a similarly undesirable racial effect, would also serve the employer's legitimate interest in efficient and trustworthy workmanship." 9s

Justice O'Connor's explanation of the evidence required to meet this lighter burden further weakened the employer's rebuttal obligation. It provided that employers need not formally validate subjective criteria in order to demonstrate their ability to predict on-the-job performance;

${ }^{91} I d$. at 2738 .

${ }^{82}$ Id.

${ }^{83}$ Id. at $2788-89$.

94 Id. at 2790 (quoting Griggs v. Duke Power Co., 401 U.S. 424, 432 (1971)).

$85 \mathrm{Id}$. at 2790 (quoting Griggs, 401 U.S. at 432, and Albemarle Paper Co. v. Moody, 422 U.S. 405, 425 (1975)) (citations omitted). 
they only need demonstrate a manifest relationship between the criteria and the legitimate goals of the employer. ${ }^{96}$ Justice O'Connor further noted that "[i]n the context of subjective or discretionary employment decisions, the employer will often find it easier than in the case of standardized tests to produce evidence of a 'manifest relationship to the employment in question." "g7 Furthermore, "[i]t is self-evident that many jobs, for example those involving managerial responsibilities, require personal qualities that have never been considered amenable to standardized testing." are generally less competent than employers to restructure business practices, and unless mandated to do so by Congress they should not attempt it." "98

Watson's extension of the scope of disparate impact is in principle a significant victory for plaintiffs in Title VII cases. Commentators agree, however, that the opinion raises more questions than it answers. ${ }^{100}$ This is due in large part to the lack of a proper foundation for the Court's ruling. The opinion did not explain adequately, for example, why subjective criteria that are alleged to be discriminatory should be analyzed under the disparate impact rather than the disparate treatment approach. Furthermore, since the plurality's restructuring of the

${ }^{86}$ See id. Among other examples, the Court quoted New York Transit Auth. v. Beazer, 440 U.S. 568, 587 n.31 (1979), in which the Court "considered it obvious that 'Iegitimate employment goals of safety and efficiency' permitted the exclusion of methadone users from employment with the New York City Transit Authority." Watson, 108 S. Ct. at $2790-91$.

This argument is rather confusing. First, it establishes a standard that seems wellnigh identical to the Court's recharacterization of the employer's burden. See supra notes $94-95$ and accompanying text. Second, the Court recasts the evidentiary burdens largely as a response to the dangers of requiring validation studies for subjective criteria. See supra notes 85-86 and accompanying text. The Court seems to undercut this rationale when it states that formal validations of subjective criteria really are not required anyway.

${ }^{87}$ Watson, 108 S. Ct. at 2791 (quoting Beazer, 440 U.S. at 587 n.31).

${ }^{88} I d$. This almost could be read as suggesting that employment decisions in some occupations so obviously require consideration of subjective criteria that their use will be considered per se valid. Decisions involving even the most discretionary positions, however, could be based on irrelevant subjective criteria.

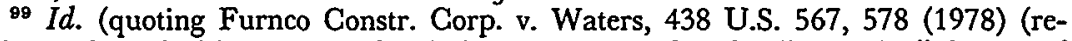
quiring only a legitimate, non-discriminatory reason for the "grapevine" hiring of bricklayers)). Taken in context, however, the Court presumably meant only that it must refrain from dictating to employers how their decision-making systems should be structured. It should not affect a relinquishment of the court's ability to determine whether practices already in place violate the law.

100 See, e.g., Powers, Not the Last Word: Court Leaves Key Bias Issues for Another Day, LeGAL TIMES, Aug. 8, 1988, at 15, col. 1 (noting the lack of a majority position on critical burden of proof questions); Impact of Supreme Court's Watson Ruling will Hinge on Disparate Impact Interpretation, 133 Daily Lab. Rep. (BNA) at C-1, C-4, C-5 (July 12, 1988) (discussing seven questions raised by Justice O'Connor's opinion). 
evidentiary burdens could well be adopted by a majority of the Court, the rationale, implications, and failings of the decision must be understood.

\section{Why Disparate Impact Is Appropriate: Providing the Missing Pieces}

This section will attempt to provide the theoretical framework, lacking in Watson, ${ }^{101}$ for applying disparate impact analysis to subjective employment decisions. The potential for discrimination inherent in the use of subjective criteria will be analyzed, as will the characteristics of the disparate treatment model which make it unsuitable for scrutinizing these criteria. Finally, those attributes of disparate impact theory that render it better equipped for such a task are discussed.

\section{A. Subjective Criteria as a Vehicle for Discrimination}

Subjective practices are not per se discriminatory. ${ }^{102}$ They are, however, vulnerable to abuse. Discrimination through subjective criteria discrimination is seldom manifested objectively in standards that can be quantified and evaluated, ${ }^{103}$ but difficulty in detection should not deter investigation into the potential of these practices as a vehicle for both intentional and unintentional employment discrimination.

As the Court cursorily acknowledged in Watson, ${ }^{104}$ subjective em-

101 See supra notes 44-100 and accompanying text.

102 See Lilly v. Harris-Teeter Supermarket, 720 F.2d 326, 338 (4th Cir. 1983) ("[B]ecause Title VII . . . prohibit[s] racial discrimination rather than simple arbitrariness or caprice, the mere existence of vague and subjective criteria is not alone proof of unlawful discrimination"), cert. denied, 466 U.S. 951 (1984); Hester v. Southern Ry. Co., 497 F.2d. 1374, 1381 (5th Cir. 1974) ("Title VII comes into play only when [subjective criteria] result in discrimination,"); supra note 77 and accompanying text. Indeed, the necessary and legitimate use of subjective practices in certain employment situations argues against a blanket prohibition. See Rogers v. International Paper Co., 510 F.2d 1340, 1345 (8th Cir.) ("[Subjective criteria] are not to be condemned as unlawful per se, for in all fairness to applicants and employers alike, decisions about hiring and promotion in supervisory and managerial jobs cannot realistically be made using objective standards alone."), vacated and remanded on other grounds, 423 U.S. 809 (1975). Courts have been highly tolerant of the use of subjective criteria involving upper level positions. See Zahorik v. Cornell Univ., 729 F.2d 85, 92-93 (2d Cir. 1984) (citing the unusual aspects of tenure decisions, such as their lifetime nature); Bartholet, Application of Title VII to Jobs in High Places, 95 HARv. L. REv. 945, 949 (1982) ("The courts have tended to show far greater deference to upper than to lower level employers ....").

${ }_{103}$ See supra notes 34-38 and accompanying text.

104 See Watson v. Fort Worth Bank \& Trust, 108 S. Ct. 2777, 2786 (1988) ("It does not follow. . . that the particular supervisors to whom this discretion is delegated always act without discriminatory intent."). 
ployment criteria can be a vehicle for intentional discrimination. ${ }^{105}$ Of greater concern, though, is the potential for unfairness even when the subjective decisionmaker lacks any discriminatory animus. In such situations, a subjective criterion such as a preliminary interview can operate as a "built-in headwind" just as the diploma and testing requirements did in Griggs. ${ }^{108}$ For instance, the decisionmaker could be unwittingly relying on subjective assessments by supervisors who were influenced by conscious, yet covert, discrimination. ${ }^{107}$ There is also the problem of subconscious stereotypes and prejudices, "a lingering form of the problem that Title VII was enacted to combat." 108 When infected with such attitudes, subjective employment decisions present the most elusive, yet potentially the most insidious, echo of formerly overt discrimination. The threat posed by hidden or subconscious stereotypes and prejudices is compounded by the tendency of people to identify more strongly with others most like them. Decisionmakers possess a "bias toward the familiar" that is distinct from and perhaps less reprehensible than the foregoing stereotypes and prejudices because it is grounded in a sense of identification rather than aversion. ${ }^{109}$ Not surprisingly, this more subtle discrimination is harder to detect and prove. ${ }^{110}$

Fears of unconscious, unintentional discrimination are not chimerical; indeed, they coincide with the evolving pattern of discrimination, which has changed from overt to more subtle forms, including subconscious stereotypes and prejudices. ${ }^{111}$ Legal approaches have been al-

${ }^{105}$ For instance, a supervisor relying solely on subjective criteria could continually overlook minority candidates for promotion. Such extreme conduct could be regarded as evidence of an intent to discriminate.

${ }^{108} 401$ U.S. 424, 432 (1971); see supra notes 16-19 and accompanying text.

107 See, e.g., Rowe v. General Motors Corp., 457 F.2d 348, 359 (5th Cir. 1972) (stating that "promotion/transfer procedures which depend almost entirely upon the subjective evaluation and favorable recommendation of the immediate foreman are a ready mechanism for discrimination against Blacks, much of which can be covertly concealed and, for that matter, not really known to management").

${ }^{108}$ Watson, 108 S. Ct. at 2786; see also R. Fear \& J. Ross, Jobs, Dollars, and EeO: How to Hire More Productive ENTry-Level Workers 18 (1983) ("We are all . . . the sum total of our inherited factors plus all the influences that have been brought to bear upon us since birth. . . . [I]f our parents had certain prejudices, such prejudices may very well have rubbed off on us, quite probably without our knowledge or awareness.").

109 See Blumrosen, supra note 36, at 18-19.

110 See, e.g., Pettigrew, New Patterns of Racism: The Different Worlds of 1984 and 1964, 37 RutGers L. Rev. 673, 686 (1985) ("Both at the individual and institutional levels, racism is typically far more subtle, indirect, and ostensibly nonracial now than it was in 1964 . . . Consequently, detection and remedy have become more difficult.").

${ }^{111}$ Congress has recognized this phenomenon. In explaining the rationale behind the expansion of EEOC enforcement power in the 1972 amendments to Title VII, the 
tered accordingly. ${ }^{112}$

\section{B. The Inadequacy of Disparate Treatment}

Given that subjective employment practices have the potential to perpetuate discrimination, they should be examined closely. Disparate treatment, however, is not the proper vehicle for such an investigation. This is true even when subjective criteria are used to further intentional discrimination, ${ }^{113}$ because in such situations the evidentiary standards associated with disparate treatment are inappropriate. First, once an employer successfully rebuts the presumption raised by a prima facie case under disparate treatment, the evidence required by the plain-

House Report noted:

Employment discrimination, as we know today, is a far more complex and pervasive phenomenon. Experts familiar with the subject [now] generally describe the problem in terms of "systems" and "effects" rather than simply intentional wrongs . . . . The forms and incidents of discrimination which the Commission is required to treat are increasingly complex.

House Comm. on Education and Labor, Equal Employment Opportunity ACT of 1972, H.R. ReP. No. 93-238, 92d Cong., 2d Sess. 8, reprinted in 1972 U.S. Code Cong. \& Admin. News 2137, 2144; see also Pettigrew, supra note 110, at 686701 (citing six features which characterize modern anti-black prejudice: (1) rejection of gross stereotypes and blatant discrimination; (2) normative compliance without internalization of new behavioral norms of racial acceptance; (3) emotional ambivalence toward black people that stems from early childhood socialization and a sense that blacks currently are violating traditional American values; (4) indirect "micro-aggressions" against blacks which is expressed in avoidance of face-to-face interaction with blacks and opposition to racial change for ostensibly non-racial reasons; (5) a sense of subjective threat from racial change; (6) individualistic conceptions of how opportunity and social stratification operate in American society).

${ }_{112}$ The approach that dominated anti-discrimination law for most of the first decade following the enactment of Title VII was the Model of Individual Justice, predicated on the belief that intentionally discriminatory decisionmaking should be prohibited, as race is almost never a factor in job performance. See Fallon \& Weiler, supra note 8 , at 13 . The practical limitations of a model that was restricted in scope to the compensation of victims of specific acts of intentional discrimination soon became evident:

[A]lso troublesome is the Model of Individual Justice's definition of discrimination: the problem may not be racial animus but racial effect; not intent to exclude individuals but practices that keep out blacks as a group; not willful decisions but continued application of criteria, often unjustified by business needs, that have a racially differential impact.

Id. at 18. By contrast, the Model of Group Justice recognizes that "current talents and abilities correlate closely with educational and cultural background," and that "the lone individual does not stand independent of history as he or she confronts the meritocratic world." Id. Thus, this model defines discrimination more broadly in terms of patterns and effects rather than intent, and is better suited to the challenges presented by unintentionally discriminatory selection practices. See id. at 19.

113 See supra notes 104-05 and accompanying text. 
tiff to establish employer pretext ${ }^{114}$ is either nonexistent, because the impressions and opinions that constitute subjective decisions are seldom recorded, ${ }^{115}$ or existent yet not readily available to the plaintiff. ${ }^{116}$ Second, the rebuttal burden requiring the defendant employer to offer a legitimate, non-discriminatory reason for the decision may be satisfied too easily. For example, an employer might respond to a prima facie case by vaguely claiming that the candidate for promotion was rejected because she could not get along well with others or because the employee selected was the best qualified. Since the employer's burden under disparate treatment is only one of production rather than persuasion, ${ }^{117}$ any subjective reason offered which appears legitimate likely will be sufficient to move the inquiry to the pretext stage, where the plaintiff continues to bear the burden of proof. ${ }^{118}$ Thus, even when subjective criteria discrimination is intentional, disparate treatment analysis poses unfair obstacles for plaintiffs.

Subjective decisions, however, also permit unconscious discrimination, which, because it is unintentional, is not covered under disparate treatment analysis by definition. Some commentators do not recognize this problem because they seem mistakenly equate to bias with intent. ${ }^{119}$ In this regard, disparate treatment generally is out of date; it is

114 See supra notes 14-15 and accompanying text.

115 This is inconsistent with the requirement in the Uniform Guidelines, supra note $24, \S 1607.4(\mathrm{~A})$, that "[e]ach [employer] should maintain and have available for inspection records or other information which will disclose the impact which its tests and other selection procedures have upon employment opportunities of persons by identifiable race, sex, or ethnic group...."

${ }_{116}$ See International Bhd. of Teamsters v. United States, 431 U.S. 324, 359 n.45 (1977) (recognizing that superior access to evidence justifies shifting the burden of proof in pattern and practice cases to the employer); see also Rose, Subjective Employment Practices: Does the Discriminatory Impact Analysis Apply?, 25 SAN DIEGo L. REv. 63, 91-92 (1988) (discussing the difficulties that arise when data showing the adverse impact of subjective procedures is unavailable).

11 See supra note 13 and accompanying text.

11 Watson presented such a situation. The Bank's "shifting use of vague and subjective criteria" frustrated the plaintiff's attempt to show pretext, as did the Bank's testimony that fifty or one hundred criteria were used in making promotion decisions. Brief for Petitioner at 6, 43-44, Watson v. Fort Worth Bank \& Trust, 108 S. Ct. 2777 (1988) (No. 86-6139); see also Bartholet, supra note 102, at 976 (claiming that in upper-level employment cases such as those involving tenure decisions, the courts "simply assert that subjective decisionmaking is appropriate," thus placing a very slight burden on the defendant); Comment, supra note 30, at 404-06 (stating that the defendant "need not convince the court that its [subjective] reason is true" in order to move the case to the pretext stage).

${ }_{110}$ See, e.g., Note, supra note 84, at 549 (arguing that an assessment of the discriminatory application of subjective evaluations requires an inquiry into intent, which is properly done under disparate treatment). A similar error is made by those who argue that hidden prejudice or bias is irrelevant; since subjective criteria are facially neutral, they are amenable to disparate impact analysis. See Rigler, supra note 31 , at $27,44-46$ (arguing that there is no basis for distinguishing between subjective and ob- 
premised on the overt discrimination of the 1960 s and the Model of Individual Justice that was the response. ${ }^{120}$

\section{The Suitability of Disparate Impact Analysis}

The weaknesses associated with using disparate treatment to analyze subjective employment practices are remedied by applying the disparate impact standard. First, disparate impact imposes reasonable evidentiary standards. Under disparate impact the focus is not on the intent behind specific instances of discrimination, but on the outcome of aggregated instances of subjective decision-making. Consequently, a plaintiff may establish a prima facie case under this standard by demonstrating that as a result of an at least partially subjective decisionmaking process, a significant number of persons in a protected class were rejected for employment. ${ }^{121}$ If the plaintiff establishes a prima facie case, the employer then has the burden of showing that the use of a challenged selection device was justified by business necessity. The business necessity defense traditionally has required more than merely demonstrating the legitimacy of a challenged practice. ${ }^{122}$ In addition, under disparate impact analysis the employer's burden is one of persuasion rather than production, as opposed to the standardless rebuttal associated with disparate treatment. ${ }^{123}$ Consequently, under disparate impact, the plaintiff would not be faced with an unduly substantial burden at the pretext stage.

A second attraction of disparate impact analysis is its focus on the process by which an employment decision is made and the specific criteria used rather than on the motives behind the decision itself. This attention to process not only simplifies evidentiary problems, it is also desirable on policy grounds, as it can expose a subtler and perhaps more insidious form of discrimination. ${ }^{124}$

This outcome comports with the mandates of Griggs and Title VII, which both aim to eliminate discriminatory effects, however caused. ${ }^{25}$ This is shown not only by their language, but also by their

jective criteria and that failure to apply disparate impact to facially neutral selection devices is inconsistent with Griggs and Title VII). This approach is flawed because a focus on facial neutrality fails to look beyond the surface of selection criteria to the characteristics of the subjective decision making process. The process allows undetectable prejudice to affect decisions and this argues for use of disparate impact analysis.

${ }_{120}$ See supra note 112.

121 See supra notes $20-22$ and accompanying text.

122 See supra notes 23-24 and accompanying text.

123 See supra notes 13 \& $117-18$ and accompanying text.

124 See supra notes 103-12 and accompanying text.

125 There has been much debate among commentators over whether the legislative 
clear choice not to differentiate between types of discriminatory employment practices. Nowhere in Griggs did the Court explicitly distinguish subjective and objective employment criteria; instead, Chief Justice Burger indicated the Court's resolve to combat discriminatory effects, whatever their source. ${ }^{\mathbf{1 2 6}}$ The Court's declaration that "good intent or absence of discriminatory intent does not redeem employment procedures or testing mechanisms" 127 may be interpreted to mean that any employment practice, be it subjective or objective, will violate Title VII if it works to exclude a significant number of minority group members. Moreover, Title VII ${ }^{128}$ and the Uniform Guidelines ${ }^{129}$ do not dis-

intent behind Title VII encompasses disparate impact. Compare Blumrosen, Griggs Was Correctly Decided-A Response to Gold, 8 InDus. REL. L.J. 443, 443-52 (1986) (adoption of adverse impact was an enlightened move which furthered the congressional aim of enhancing employment opportunity for minority groups and women) and Helfand \& Pemberton, The Continuing Vitality of Title VII Disparate Impact Analysis, 36 MERCER L. REv. 939, 941-62 (1985) (the statutory language of the original Civil Rights Act and the legislative history of the 1972 amendments support the disparate impact principle) and Thompson, The Disparate Impact Theory: Congressional Intent in 1972-A Response to Gold, 8 INDus. REL. L.J. 105, 105-06 (1986) ("Congress approved the disparate impact theory and ratified Griggs when it amended Title VII in 1972 . . . .") with Gold, supra note 25, at 564-78 (Congress did not adopt the adverse impact theory established in Griggs) and Gold, Reply to Thompson, 8 INDUS. REL. L.J. 117, 117 (1986) (same).

${ }^{128}$ Nothing in Griggs suggests that the Court intended to limit disparate impact cases to only those involving objective criteria. The Court instead chose to describe employment practices broadly: "Nothing in the Act precludes the use of testing or measuring procedures; obviously they are useful. What Congress has forbidden is giving these devices and mechanisms controlling force unless they are demonstrably a reasonable measure of job performance." Griggs v. Duke Power Co., 401 U.S. 424, 424 (1971) (emphasis added).

${ }_{127}$ Id. at 432 .

${ }^{128}$ As interpreted by the Supreme Court,

The objective of Congress in the enactment of Title VII is plain from the language of the statute. It was to achieve equality of employment opportunities and remove barriers that have operated in the past to favor an identifiable group of white employees over other employees. Under the Act, practices, procedures, or tests neutral on their face, and even neutral in terms of intent, cannot be maintained if they operate to 'freeze' the status quo of prior discriminatory employment practices.

Id. at $429-30$.

${ }^{129}$ See Uniform Guidelines, supra note $24, \S 1607.16(Q)$ ("selection procedure" includes "the full range of assessment techniques from traditional paper and pencil tests, performance tests, training programs, or probationary periods and physical, educational, and work experience requirements through informal or casual interviews and unscored application forms"). The EEOC expanded on the Guidelines by stating that the regulations applied not only to written tests, but to "all selection procedures used to make employment decisions, including interviews, review of experience or education from application forms, work samples, physical requirements, and evaluations of performance." Adoption of Questions and Answers to Clarify and Provide a Common Interpretation of the Uniform Guidelines on Employee Selection Procedures, 44 Fed. Reg. 11,996, 11,997 (1979).

The Guidelines have been accorded substantial weight by the Court in interpret- 
tinguish between objective and subjective criteria. Rather, they emphasize the consequences of selection practices, with a broader purpose of eliminating employment criteria that operate as "artificial, arbitrary, and unnecessary barriers to employment"130 for minority groups and are unrelated to measuring job capability.

\section{THE Watson Plurality's Solution}

The plurality's structuring of the evidentiary burdens departs substantially from that of traditional disparate impact analysis in two critical ways. First, the plurality's approach makes it more difficult for the plaintiff to establish a prima facie case of discrimination. Second, the plurality makes it markedly easier for the employer to defend such an allegation. These new obstacles, in turn, may frustrate the purposes of Title VII by deterring subjective criteria suits. Furthermore, Justice O'Connor's allocation of the evidentiary burdens may represent at least a partial collapsing of the disparate impact and disparate treatment tests into the same analysis.

\section{A. Plaintiffs Prima Facie Case}

In addition to demonstrating that an employer's selection system chooses applicants from protected groups for hire or promotion in a "pattern significantly different from that of the pool of applicants,"131 a plaintiff in a subjective practice case "must begin by identifying the specific employment practice that is challenged."132 This new requirement was inserted to deter "cumulative effects" complaints which allegedly force an employer to defend its entire system of employment practices. ${ }^{133}$ The plurality shed little light on what constitutes identification of a practice. ${ }^{134}$ If identification is intended to focus the inquiry and

ing Section 703(h) of the Act. See McDonald v. Santa Fe Trail Transp. Co., 427 U.S. 273, 279 (1976) (holding that EEOC's interpretations are "entitled to great deference"); Griggs, 401 U.S. at 433-34 ("The administrative interpretation of the Act by the enforcing agency is entitled to great deference. Since the Act and its legislative history support the Commission's construction, this affords good reason to treat the guidelines as expressing the will of Congress." (citations omitted)).

${ }^{130}$ Griggs, 401 U.S. at 431.

131 Albemarle Paper Co. v. Moody, 422 U.S. 405, 425 (1975); see supra notes 2022 and accompanying text.

132 Watson v. Fort Worth Bank \& Trust, 108 S. Ct. 2777, 2788 (1988); see supra notes $91-93$ and accompanying text.

133 See supra notes 87-89 and accompanying text.

134 It would be unduly harsh to read the plurality's use of "practice" in the singular, see Watson, $108 \mathrm{~S}$. Ct. at 2788 , Constraining a plaintiff who has a legitimate basis for attributing a disparity to more than one criterion. One can envision a situation in which there are two subjective practices, such as a performance rating by a supervisor 
thereby avoid overbroad attacks, this could be accomplished by simply having the plaintiff state what she believes to be the offending practice. The plaintiff should not, however, simply identify the allegedly discriminatory criterion, but she also should provide some evidentiary support for her claim. ${ }^{135}$

There are two difficulties presented by the identification requirement. An employer's decision-making process may be so amorphous as to render identification impossible. ${ }^{138}$ Strict enforcement of the identification requirement could provide employers with an incentive to make their decision making process deliberately vague. ${ }^{137} \mathrm{~A}$ second potential problem concerns the unfairness of requiring an unsuccessful applicant for employment to understand the employer's decision-making process sufficiently to pinpoint the criterion that was responsible for the alleged discrimination. Furthermore, the statistical evidence detailing the effects of the criterion are unlikely to have ever been available to the plaintiff. ${ }^{138}$

Not only did the plurality add an identification element to what a plaintiff must prove as part of her prima facie case, it also reduced the effect of the prime facie showing once it is made. This latter alteration follows deductively from the refashioning of the employer's rebuttal obligation. The reduced burden now shouldered by the defendant indicates that the plurality views the prime facie case merely as raising an inference of discrimination, reminiscent of the easily rebuttable pre-

and an interview, which work together to produce a significant adverse impact. $C f$. Griggs, 401 U.S. at 425-26 (involving two objective practices, the requirement of high school education and the administration of standardized intelligence tests). Permitting the plaintiff to challenge only one of these devices would be counterproductive. Even if a plaintiff were to challenge successfully one practice, under such a narrow reading an employer in theory would be able to continue using the second device until it too was attacked.

130 Suppose, for example, that a plaintiff establishes a significant disparity in the employer's workforce and attributes this to an interview required of all applicants for employment. The defendant then would rebut this showing either by arguing that the identified practice does not result in a disparity or that there is a legitimate business reason for the disparity. Should the defendant choose the former approach, the plaintiff would have to introduce further and more convincing evidence of a disparity if she is to meet the burden of persuasion.

${ }^{136}$ This situation is particularly likely to arise in challenges to the selection systems of small businesses, such as Fort Worth Bank \& Trust, or closely-held firms whose size and informality are not conducive to highly formalized decision making systems.

137 Justice Blackmun appreciated this danger and cautioned that the identification requirement cannot be used "to shield from liability an employer whose selection process is so poorly defined that no specific criterion can be identified with any certainty, let alone be connected to the disparate effect." Watson, 108 S. Ct. at 2797 n.10 (Blackmun, $J$., concurring in part and concurring in the judgment).

${ }_{138}$ See supra notes $114-16$ and accompanying text. 
sumption created under disparate treatment analysis, rather than actually constituting proof of discrimination.

\section{B. The Employer's Rebuttal Burden}

Once the plaintiff's prima facie claim of discrimination has been established, the defendant in a traditional disparate impact case is charged with "the burden of showing that any given requirement [has] a manifest relationship to the employment in question."139 Prior to Watson, the Court previously had placed upon the employer the burden of proving, not merely explaining, that a particular practice is warranted as a business necessity. ${ }^{140}$ In Watson, however, the Court surprisingly and without adequate explanation recast this rebuttal burden, at least insofar as subjective criteria cases are concerned. It first reduced the employer's burden from one of persuasion to one of producing evidence that its employment practices are based on legitimate business reasons, ${ }^{141}$ a standard that is considerably easier to meet. It then rather confusingly stated that in order to meet that burden, employers need not formally validate their objective criteria, they need only establish that the criteria serve legitimate goals. ${ }^{142}$

The problem with this restructured rebuttal burden is that the Court, in effect, threw the baby out with the bath water. The Court attempted to prevent what it saw as unfortunate secondary effects from the application of disparate impact analysis to subjective criteria, ${ }^{\mathbf{1 4 3}}$ but in the process constrained Title VII plaintiffs to an extent unwarranted by the foreseeable dangers.

\section{Plaintiffs Burden of Proof}

Once an employer has responded to a prima facie case by meeting its burden of production, the plaintiff must persuade the court that there is an alternative selection device which would not have as adverse an impact and still would serve the needs of the employer. ${ }^{144}$ In outward appearance, this is the same standard as applied in conventional disparate impact cases. Due to the changed nature of the employer's burden as formulated in Watson, however, the requirement of proving a less injurious alternative effectively shifts the business necessity bur-

139 Griggs, 401 U.S. at 432.

${ }^{140}$ See supra notes 23-24 and accompanying text.

${ }^{141}$ See supra notes $94-95$ and accompanying text.

${ }^{142}$ See supra note 96 and accompanying text.

${ }^{143}$ See supra notes 81-89 and accompanying text.

${ }^{144}$ See supra notes 25-26 and accompanying text. 
den to the third stage of the analysis, and hence to the plaintiff. In order to prevail, the plaintiff in a subjective criteria case first must devise an alternative selection practice, and then validate it. It is not clear why the plurality assumed that plaintiffs know which available systems are appropriate for the defendant's business. ${ }^{145}$ Yet even if the plaintiff were to accomplish this task, the employer still could prevail if it raised legitimate considerations, such as the "cost or other burdens of proposed alternative selection devices"146 which would indicate that the proposed solution did not meet the employer's needs.

In sum, the plurality's restructuring of the order and allocation of proof has the following effects: (1) it adds an element to the traditional concept of the prima facie disparate impact case and reduces the benefit to the plaintiff from such a showing; (2) it substantially lessens both the nature and content of the defendant's rebuttal burden; (3) it markedly increases the burden on the plaintiff at the pretext stage. Quite possibly, then, the plurality's position in Watson, if adopted by a majority of the Court, could operate as a "built-in headwind"147 for plaintiffs in subjective criteria cases.

\section{The Threat to Disparate Impact Analysis}

A further disturbing aspect of Watson is the plurality's suggestion that the new evidentiary standards extend to all disparate impact cases, both subjective and objective. ${ }^{148}$ If so, this would indicate that at least a partial collapse of the disparate impact and disparate treatment models has occurred, one which would frustrate the independent bases supporting impact analysis. ${ }^{149}$ This is suggested both by the way the plurality's burden allocation closely resembles that used in disparate treatment cases and by the underlying rationale which the Court seems to have

145 See supra notes $115-16$ and accompanying text.

${ }_{148}$ Watson v. Fort Worth Bank \& Trust, 108 S. Ct. 2777, 2790 (1988). One example of "other burdens" might be the difficulty in implementing the proposed alternative.

${ }_{147}$ See Griggs v. Duke Power Co., 401 U.S. 424, 432 (1971).

${ }^{148}$ See, e.g., Watson, 108 S. Ct. at 2788 n.2 ("[W]e do not believe that each verbal formulation used in prior opinions to describe the evidentiary standards in disparate impact cases is automatically applicable in light of today's decision."); $i d$. at 2788 ("Our previous decisions offer guidance, but today's extension of disparate impact analysis calls for a fresh and somewhat closer examination of the constraints that operate to keep that analysis within its proper bounds." (footnote omitted)). But cf. id. at 2786 (" $[W]$ e must determine whether . . . disparate impact analysis . . . can be applied in this new context under workable evidentiary standards.").

${ }_{140}$ See The Supreme Court, 1987 Term-Leading Cases, 102 Harv. L. REv. $143,308-20$ (1988) (discussing Watson and asserting that the division over the evidentiary burdens may indicate that the Court is reconsidering the theoretical underpinnings of disparate impact). 
adopted for disparate impact analysis.

It bears repeating that disparate treatment analysis focuses exclusively on the intent of the decisionmaker while disparate impact analysis focuses on the effect an employment practice has on a protected group. ${ }^{150}$ Under disparate treatment analysis, a prima facie case raises a presumption of illicit intent since it is presumed that discrimination is the only plausible explanation. A prima facie case under the disparate impact approach means that a discriminatory effect has been proven directly, largely by statistical evidence. With regard to the employer's rebuttal, only the burden of production shifts under the disparate treatment standard, while under the traditional disparate impact standard the burden of persuasion also shifts. Finally, as to the degree of evidence necessary to rebut a prima facie case, the employer in a disparate treatment case only need explain the differential treatment; under traditional disparate impact analysis the employer must prove business necessity.

As Justice Blackmun explains in his concurrence, "[ $t]$ he plurality's suggested allocation of burdens [for subjective criteria cases] bears a closer resemblance to the allocation of burdens we established for disparate-treatment claims."151 The plurality's restructuring is indeed "a near-perfect echo" of the Court's disparate treatment opinions. ${ }^{152}$ The ultimate burden of proof remains with the plaintiff whose prima facie case raises only an inference of discrimination, while the defendant's burden is one of mere production and may be met by offering facially legitimate business reasons.

Watson's restructuring of the evidentiary burdens also undermines the theoretical underpinnings of traditional disparate impact analysis. ${ }^{163}$ Elements of the plurality's ruling indicate that it has adopted a proxy theory which effectively views the establishment of adverse impact merely as a surrogate method for proving intentional discrimination. ${ }^{154}$ According to this theory, if a test, interview, or experience re-

180 See supra notes 7-9 and accompanying text.

151 Watson, 108 S. Ct. at 2792 (Blackmun, J., concurring in part and concurring in the judgment).

${ }_{182}$ Id. Compare, for example, Justice O'Connor's statement regarding the "ultimate burden of proof," see supra text accompanying note 95, with Justice Powell's view that under disparate treatment, "[t]he ultimate burden of persuading the trier of fact that the defendant intentionally discriminated against the plaintiff remains at all times with the plaintiff." Texas Dep't of Community Affairs v. Burdine, 450 U.S. 248, 253 (1981) (citations omitted).

15s See supra note 8-9 and accompanying text.

104 The disparate impact theory has been described as the "weak" version of the Model of Group Justice, see Fallon \& Weiler, supra note 8, at 20, merely supplementing the Model of Individual Justice, because "discriminatory impact has its moral and theoretical force as evidence of intentional, race-based decision-making." Id. 
quirement is shown to exclude large numbers of a protected group, then the practice itself has become a "proxy" for race, gender, or any other impermissible factor. The statistically significantly adverse impact of the practice indicates McDonnell Douglas discriminatory intent. ${ }^{185}$ Recharacterizing the effect of the plaintiff's prime facie showing in this manner allows the plurality, for evidentiary purposes, to treat the case as one of disparate treatment. Consequently, the demonstrated effect of a neutral practice raises only an inference of discrimination and shifts the burden of production, rather than persuasion, to the defendant. The end result is a circumvention of the more favorable burden allocation afforded to plaintiffs under the disparate impact standard.

Fearing that the unanimous decision to apply disparate impact to subjective selection practices strayed too far from the realm of intent, the Watson plurality imposed constraints to keep the analysis within its proper bounds, appearing to take with one hand what had just been given with the other. ${ }^{156}$ The Court's attachment to intent, under the proposed burden allocation system, is likely sharply to limit the utility of disparate impact as a basis for Title VII claims. Thus, the bold step the Court has taken in applying impact analysis to subjective employment practices ultimately may make little headway toward eradicating modern forms of discrimination.

\section{Talloring the Means to Fit the End: An Alternative Approach to Subjective Griteria Evidentiary Burdens}

The Watson plurality's decision to apply disparate impact to subjective employment decisions was correct. ${ }^{157}$ The court was insufficiently flexible, however, in devising appropriate evidentiary burdens. This section suggests an alternative approach by accepting some of the plurality's requirements, modifying others, and rejecting those that ultimately lead to the merger of the two theories of Title VII discrimination.

First, the threat of broad cumulative effects complaints ${ }^{158}$ is sufficient to warrant the requirement that the plaintiff, as part of her prima

155 See supra notes 10-11 and accompanying text.

186 See Watson, $108 \mathrm{~S}$. Ct. at $2788-91$ (requiring plaintiff to identify the specific employment practice challenged, to prove a causal relationship between the practice and plaintiff's exclusion, to offer reliable statistical evidence, to bear the burden of persuasion at all times, and not requiring defendants to introduce "validation studies" showing that particular criteria predict job performance).

157 See supra notes 113-30 and accompanying text (arguing that disparate impact analysis permits plaintiffs to overcome obstacles in proving discrimination that are insurmountable under disparate treatment analysis).

158 See supra notes 87-89 and accompanying text. 
facie case, identify the employer's practice or practices that she believes in good faith are responsible for the disparity. ${ }^{159} \mathrm{~A}$ plaintiff's ignorance of an employer's procedures and her lack of access to data ${ }^{\mathbf{1 6 0}}$ would be cured largely by discovery. To the extent, however, that such information is unavailable because the employer failed to comply with EEOC record-keeping requirements, ${ }^{161}$ the burden of defending its entire system should rightfully be borne by the employer. The employer also should bear this burden when its decision- making system is too vague or incoherent for the plaintiff to isolate a culpable component. ${ }^{\mathbf{1 6 2}}$

Commensurate with the increased responsibility of the plaintiff, the employer's rebuttal burden in subjective criteria cases should be the same as that imposed under traditional disparate impact analysis. ${ }^{\mathbf{1 6 3}} \mathrm{An}$ employer should be required to rebut the plaintiff's prima facie case by offering statistical evidence that is more accurate or relevant, or by persuading the court of the business necessity of its subjective practice. The Supreme Court has described the business necessity requirement in a number of ways ${ }^{164}$ and it is not the purpose of this Comment to offer a precise definition. It is sufficient to say that an employer should be required to do more when rebutting a prima facie case than simply to provide a legitimate business reason for a subjective practice. ${ }^{165}$

Strengthening the employer's burden of persuasion will not lead, as the plurality feared, to the wholesale adoption of quota systems. It must be acknowledged that the use of subjective criteria in employment decisions is warranted, particularly when the job in question possesses a significant discretionary component. Given employers' legitimate

169 See supra notes $91-93$ and accompanying text.

160 See supra notes $114-16$ and accompanying text.

181 See supra note 115. The importance of compliance with these requirements is demonstrated by the Uniform Guidelines' provision specifying that where an employer has failed to maintain data on adverse impact, federal enforcement agencies are permitted to draw an inference of adverse impact in the selection process. See Uniform Guidelines, supra note 24, § 1607.4(D); see also Rose, supra note 116, at 92 (for jobs where subjective criteria serve as the sole basis for decisionmaking, an employer may satisfy its burden by showing that the only procedures available for use in the decision were discretionary and that the employer complied with the record keeping requirements of the Uniform Guidelines).

${ }^{162}$ Cf. supra notes 136-37 and accompanying text (requiring strict identification of the challenged practice may encourage the use of vague decisionmaking processes).

1es See supra notes 23-26 and accompanying text.

104 In Griggs alone the Court refers to the employer's burden alternatively as "business necessity," "related to job performance," and "manifest relationship to the employment in question." Griggs v. Duke Power Co., 401 U.S. 424, 431-32 (1971).

${ }_{18 s}$ See Watson v. Fort Worth Bank \& Trust, 108 S. Ct. 2777, 2794 (1988) (Blackmun, J., concurring in part and concurring in the judgement) ("The term [business necessity] . . . goes a long way toward establishing the limits of the defense: To be justified as business necessity an employment criterion must bear more than an indirect or minimal relationship to job performance." (citations omitted)). 
needs for subjective practices, it would be undesirable to force firms into "objectifying" their selection systems. To the extent that the plurality describes subjective criteria as "obvious," "plainly relevant," or "self-evident," in order to caution against the wholesale abandonment of subjective decisionmaking, its point is well taken. The context in which these statements are made, however, creates a danger that they will be read as reducing, or perhaps even eliminating, the scrutiny to which the variety of subjective practices should be subjected. Reducing such scrutiny avoids the evil of quotas at the expense of making little, if any, headway against the discriminatory abuses inherent in discretionary decision-making. Returning to the traditional disparate impact rebuttal burden would permit a balancing of the employer's business interests ${ }^{168}$ against those of the plaintiff (and society generally) in eradicating discrimination.

Procedural considerations should play a part in assessing the validity of a subjective employment practice. ${ }^{167}$ The presence of procedural safeguards can remedy a troubling aspect of subjective decisionmaking, namely the lack of employer accountability, by giving protected groups a voice in the decision-making process, ${ }^{168}$ including an opportunity to obtain review. Of equal importance, being able to demonstrate the procedural integrity of its decision-making process would reduce the pressure on an employer to use only objective criteria that can easily be

168 See Texas Dep't of Community Affairs v. Burdine, 450 U.S. 248, 259 (1981) (Title VII was not intended to "diminish traditional management prerogatives").

167 For a comprehensive discussion of such considerations, see B. SCHLEI \& P. Grossman, supra note 7, at 202-05 (listing such factors as completing a job analysis, providing raters with specific guidelines and establishing an appeal process or reviewing committee); see also Rowe v. General Motors Corp., 457 F.2d 348, 358-59 (5th Cir. 1972) (considering five such factors-including heavy reliance on the recommendation of a foreman who was provided with no written instructions regarding the qualifications necessary for promotion, the use of vague and subjective standards, absence of notice of promotion opportunities, and the lack of procedural safeguards-as important to the determination that Title VII had been violated); Blumrosen, supra note 36 , at 34-37 (discussing factors that appear to influence judicial decisions in subjective judgment cases); Denis, Subjective Decision Making: Does It Have a Place in the Employment Process?, 11 EMPLOYeE REL. L.J. 269, 282-87 (1986) (listing preventive measures to minimize risk of liability); $c f$. Waintroob, supra note 21, at 47-62 (discussing the use of subjective criteria in white-collar cases and arguing that in this context courts are more tolerant of subjective practices if the decision-making procedure is fair and safeguarded).

The considerations of cost and "other burdens" proposed by the Watson plurality, see supra note 146 and accompanying text, are too nebulous to be of any real assistance to the inquiry.

${ }^{168}$ Cf. Royal v. Missouri Highway \& Transp. Comm'n, 655 F.2d 159, 164 (8th Cir. 1981) (subjective decisions should be scrutinized closely when the decisionmakers are not members of a protected class). 
validated scientifically, thereby eliminating the attraction of quotas. ${ }^{160}$ The availability of procedural safeguards, a resource notably untapped by the Watson plurality, argues against the need to reduce the employer's rebuttal burden to one of mere production.

In sum, a plaintiff challenging a subjective employment criterion under Title VII should have to establish a prima facie case by identifying, where possible, the culpable practice and demonstrating that it has a statistically significant adverse effect on members of a protected class. This prima facie case would be sufficient to prove that discrimination actually had occurred, as under the traditional disparate impact standard. ${ }^{170}$ The employer, in turn, should bear the burden of persuasion as to the business necessity of its practice, a burden which at least in part may be met by proof that procedures were in place to guard against abuse of discretion. Once this rebuttal burden is met, the plaintiff should have the opportunity, as under traditional disparate impact analysis, to undercut the weight of the employer's alleged business necessity by alleging that the proffered justification is merely a pretext for discrimination.

\section{CoNCLUSION}

The Supreme Court's decision in Watson v. Fort Worth Bank $\mathbb{E}$ Trust ${ }^{171}$ answered in the affirmative the important question of whether disparate impact analysis may be used to mount a Title VII challenge to employment decisions based wholly or partially on subjective judgments. ${ }^{172}$ The decision, however, created uncertainty as to whether Title VII plaintiffs will reap the benefits of the Court's ruling. ${ }^{173}$ The uncertainty is at base due to the Court's failure to articulate properly the differences between subjective and objective criteria, choosing to focus instead on the dichotomy between intentional discrimination and unintentional practices having a discriminatory effect. ${ }^{174}$ While this focus ultimately leads the Court to the correct determination, it does so at the expense of a proper foundation. The implications of this flaw are manifested most vividly in the plurality's inappropriate allocation of the evidentiary burdens among plaintiffs and employers in subjective crite-

\footnotetext{
169 See supra notes 82-86 and accompanying text.

170 See supra note 20 and accompanying text.

171108 S. Ct. 2777 (1988).

172 See supra notes 65-66 and accompanying text.

173 See supra notes 131-55 and accompanying text (criticizing the Court's identification requirements, its recasting of the employer's rebuttal burden, and its increasing of the plaintiff's burden at the pretext stage).

174 See supra note 76 and accompanying text.
} 
ria suits. ${ }^{178}$ The result does more than just discourage plaintiff's from pursuing their Title VII rights. It comes dangerously close to rendering disparate impact analysis indistinguishable from disparate treatment, thereby eliminating a much needed theory of recovery against modern forms of discrimination. ${ }^{178}$

More fundamentally, there is an underlying tension in the Court's analysis as to whether "discrimination" consists of limited opportunity or whether it requires, albeit in a more subtle manner, evidence of illicit intent. ${ }^{177}$ By indirectly clinging to the notion of intent embodied in the proxy rationale, it would seem that the Supreme Court has not recognized fully the subtle and manifold forms of current discrimination. This failure could be remedied by adopting this Comment's suggestions for restructuring the evidentiary burdens in subjective criteria cases. The resulting more balanced allocation between plaintiffs and employers avoids the harms feared by the plurality, while at the same time providing a way of policing the adverse impact of subjective criteria. By enhancing the ability of minority group members to protect their Title VII rights and by minimizing the intrusion into employers' management prerogatives, the end result would be a closer observance of the mandate of Title VII to "eliminate all aspects of discrimination."178 